\title{
USING THE INTERNET IN THE DECISION MAKING PROCESS CONCERNING THE PURCHASE OF TOURIST OFFERS
}

\author{
ANNA PRZYBYLSKA \\ Adam Mickiewicz University, Poznań, POLAND \\ e-mail: aprzybyl@amu.edu.pl
}

KEYWORDS | information society, e-tourist, purchase decisions

ABSTRACT A more and more considerable factor that contributes to change is the continued development and dissemination of new information and communication technologies. Information and communication technology have led to considerable changes in people's communication, making it possible to disseminate information not only via traditional media platforms. Owing to Internet companies can create their own communication channels aimed directly at present and future customers. The paper aims at identifying the possibilities of using the Internet in the process of taking and realizing purchase decisions regarding tourist services. The paper is devoted to important transformations that tourism is subject to by promoting information and communication technology. The Internet and mobile technologies change both the media space and the way companies and consumers communicate.

\section{Introduction}

With new technologies constantly appearing there are changes to the labour market and the way in which social life is organised. There is an increasing number of digital goods and services which raise people's standard of living. The fact that it is easy to sell services online because of lower costs and the convenience of all those concerned causes such services to become some sort of threat to the same ones sold in a traditional way. At the start of the 21st century Internet researchers 
created the vision of watching the entire world without leaving home. The rapid development of electronic technology allowed it to help advance tourism by putting the technology into practice. Such activities were largely dictated by tourists' rising awareness and expectations. In the literature it is difficult to find a reference to e-tourism, which is usually mentioned as a way of promoting the image of a tourist product, or, in more popular terms, selling tourist services via the Internet.

The constant information development and knowledge improvement gave rise to the term "information society" in Japanese social sciences in the 1960s (Karvalics, 2007). Numerous research definitions and approaches prove the complexity of the problem. In general, the most important message is information and knowledge. As noted by Cellary (2002), the term "information society" pays attention to the word information, although knowledge is more important when it comes to a human being, because it is indispensable for acquiring, understanding and creating information.

The information society is characterised by being prepared and able to make use of information systems. It is a computerised society that uses telecommunication services to transmit and process information remotely (the first Congress of Polish Information Technology, 1994). From a simpler definition that refers directly to the role of consumer it can be inferred that the term "information society" is used to describe a society in which individuals as consumers or employees make intensive use of information (Kubicek, 1999). Despite numerous definitions the most significant one is that by Goba-Klas and Sienkiewicz (1999), who employs the term to specify a society that has developed means of information processing and communication and the means are the basis for creating national income and the main source of livelihood for most of the society.

The notion of the information society as the main factor of social and economic progress is a fairly well-researched phenomenon. Work in the area was pioneered by Bell (1973), who the first to use the term "post-industrial society". The phrase referred to a society of services (earlier the idea of a production of goods society was recognised). To some degree the concept extended Machlup's term (1962), who was the first to use the phrase "information society". Several years later the significance of the social group was stressed by Drucker (1968) in his analysis of the postcapitalist society, which he also viewed as a knowledge-based society. All the previous research was the basis of Porat's work (1977), who studied the information economy and the information sector. However, at present the most up-to-date ideas seem to be those by Toffler (1980), who presented the concept of "the third wave" and identified an information-based post-industrial civilisation. An introduction to the discussion of the Internet being omnipresent in the social and economic life can be found in Castells (1998), who showed the correlation between the changes in the conditions and style of social life, a knowledge-based economy and the universality of computerisation.

Despite Poland's technological diversification being different from that in other European countries (Internet infrastructure and access is lower than the average in European countries ${ }^{1}$ ), Internet users are more and more increasingly willing to search information about tourist products in the market. The Internet is becoming a more and more popular information source for prospective clients that plan both leisure and business trips.

${ }^{1}$ A. Tarkowski, Analiza społecznych uwarunkowań dostępu do Internetu, http://zds.kprm.gov.pl/sites/default/files/ analiza_alek_tarkowski.pdf, 2009. 
At the same time a network society, which is characterised by high internet usage, is provided with endless opportunities that stem from interactive access to all the goods offered by the world. First of all the access is changing us, the way we function and radically alters numerous branches that are key to society.

The aim of the paper is to identify the possibilities of using the Internet in the decision making process concerning the purchase of tourist services and to signal a new model of tourist: an e-tourist that has progressed from the previous e-consumer. The paper is both diagnostic and prognostic and describes how processes related to among other things Internet development will influence tourism development. As a consequence, there are also general recommendations for tourist companies which should be the most interested in communicating information to a new model of tourist, i.e. e-tourist. The work is a diagnostic overview and is primarily based on social structural diversification. Generally, one might be tempted to say that the structure to some extent corresponds to the development of a particular society and changes that have been taking place over the years that have contributed to the e-tourist emerging.

\section{Using the Internet in tourism}

The increasing use of smartphones and tablets has revolutionised the way and rate of communication with consumers, too. A contemporary customer is homo informaticus - he or she is apt at using technology and searching indispensable information in numerous sources. In order to reach him or her, it is worth using trends that have been appearing. Technological advance has also contributed to the rise of e-consumer. An e-consumer is a private individual that shows and meets his or her consumer needs through products (goods and services) purchased in the Internet. Defining the category of e-consumer makes it possible to identify the category of e-behaviours. Any individual's reactions to stimuli from the outside world - both real and virtual - can be regarded as e-behaviours. They may be passive (e.g. reading web pages, browsing the websites of companies providing services, auctions and online shops, using email) and active (e.g. posting comments, running a blog, using communicators, buying online, using online services, participating in Internet forums and virtual communities) (Figure 1) (Jaciow, Wolny, 2011).

The universality of the Internet contributes to the fact that consumers cease to be passive recipients of often one-sided advertising messages. They are more and more eager to consciously search for reliable and proven information based on opinions of their friends, families or other credible people from a stakeholder's point of view. Such a universality is not beneficial to consumers only. Companies, too, find it much easier to reach consumers in order to recognise their needs and ultimately sell their products. The development of the Internet is not limited to universal access to information. The access is becoming boundless as mobile devices are gaining in popularity, which as a consequence results in mobile Internet becoming increasingly widespread. This trend is visible all over the world and is mainly caused by us functioning in the so called nanosecond culture. Since consumers are in constant rush, dashing from one place to another, they expect everything to be available right here and right now (Hatalska, 2011). 


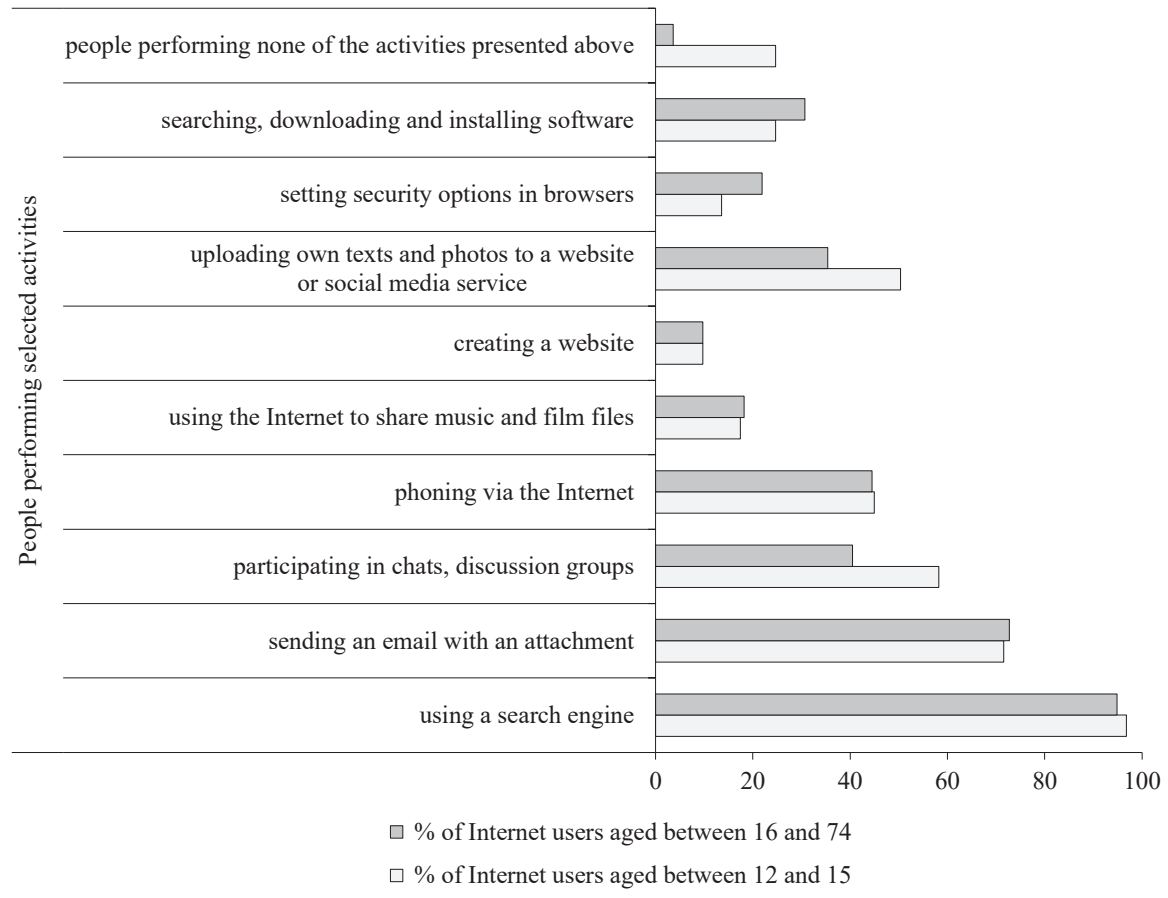

Figure 1. People using the Internet and performing various activities in 2014

Source: Spoleczeństwo informacyjne w Polsce w 2014 roku, GUS w Szczecinie, Warszawa 2014.

Many researchers believe that the most important factor that defines the frequency of Internet use is age. The biggest group (98.3\%) that not only has access to the Internet, but also uses it actively comprises people aged between 16 and 24. The most important features that Internet activity in this demographic group depends on are mobility, a strong desire to learn about new things and, to a large extent, addiction to the Internet and mobile phones. A slightly smaller group of Internet users is comprised of people aged between 25 and 34 (90.8\%) and those aged between 35 and 44 (79.5\%). People aged 45 and more are using the Internet much less frequently. The proportion of active users aged between 45 and 54 amounts to only $57.9 \%$ whereas those aged 55 or more to an average of $27.1 \%$ (Kalecińska, 2013). The rapid development of the Internet has led to consumer $\mathrm{C}$ being differentiated from consumer L. The differentiation stems first of all from patterns of behaviour and not demographic features, as used to be the case. Although the current development of technology creates the same skills and needs as far as using the services in the Internet is concerned, the differentiation can be made based on certain features. Generation $\mathrm{C}$ is a generation that is willing to have influence and control over what appears in the Internet. The consumers create, comment and assess - they feel the need of becoming known in the virtual world. Generation L, in turn, is the one that distributes content which has already appeared in the Internet, e.g. through various social media (Driggs, 2012). 
The Internet enables not only diminishing the impact of mass message, but also finding the best offers and comparing prices instantly thanks to the popularity of web browsers, forums and social media. Even if a customer makes a decision regarding a product or a service found on the Internet and he or she completes it in a traditional company, he or she already has a strictly defined plan as to the destination and the offered price. To date consumers' patterns of purchase decisions have been concentrated on three principal factors: advertising messages, direct contact with a product and possible subsequent experiences related to use of the product. When buying holidays consumers used to be influenced by fashion, their friends' and families' opinions, their habits and the need to experience something new in their choice of destination.

Purchase decisions are made depending on the users being active in the Internet. More and more often consumers have permanent access to new information that helps them take more reasonable buying decisions and react less spontaneously during the process, which confirms a higher degree of consumer awareness on their part. In addition, when features of information society are considered, the buyers do not keep the information to themselves, but share it with others, which impacts purchase decisions by other potential customers. Such opinions are often of greater value than a typical advertisement of products and services. According to Nielsens's report titled "Trust In Advertising” (Global Trust in Advertising, 2012), 90\% of respondents take purchase decisions based on recommendations from people they know and as many as $70 \%$ make the same decision guided by information published online.

The technological advancement enables us to make a purchase in every moment of our lives, regardless of whether we are at home, at work or travelling. All information is within easy reach. The importance of decision making stems first of all from several facts:

- $62 \%$ of all buyers in the world are digital consumers. Buying online is gaining in significance even of most transactions are made traditionally,

- digital consumers can be divided into three groups according to their most frequent behaviours: digital informers, digital purchasers and digital multitaskers,

- multitaskers are the most informed, the most versatile and the most demanding consumers as to whom awareness needs to be raised, as there are more and more of them from year to year,

- Although digital technologies greatly enrich traditional forms of purchase and play a significant role in the buying process (even of it is completed in a stationary shop), consumers' purchase decisions are still largely influenced by recommendations from friends and second-hand opinions (whisper marketing) (Driggs, 2012).

Drigs (2012) defines digital consumers as people using the Internet during the purchase decision making process in at least 5 out of 10 main categories ${ }^{2}$ of products and services. This means that these are people who search information about a product or a service in the Internet or buy directly from the Internet before they make a purchase online or offline. The biggest group

21 - Mobile and landline telephony, 2 - Consumer electronics, 3 - House insurance, 4 - Goods, 5 - Clothing, 6 - Health insurance, 7 - Consumer credit, 8 - Health protection, 9 - Food and drinks, 10 - Cars. 
$(63 \%)$ of digital consumers is made up of digital informers whose behaviours are characterised by the following major elements:

- they treat the online channel solely as a source of information,

- purchases are mainly made in traditional shops,

- consumers have greater loyalty towards a particular brand,

- they spend the least time online among members of the entire group of digital consumers.

The least numerous group is that of digital buyers - only $13 \%$ of the whole society. Their most important features include:

- they mainly use the Internet to make a purchase,

- the decision to buy is primarily influenced by product price and availability;

- a brand, ethics, social responsibility do not have much impact on buying decisions,

- they express a higher preference for credit card payments,

- they show a relatively high level of approval of mobile devices.

Digital multitaskers are included in the middle group, over which entrepreneurs may have potentially the biggest influence. This primarily stems from several facts:

- mixing offline and online channels both during a product or service and making a purchase,

- as a general rule the group comprises people with better education and higher income than those in the two previous consumer groups,

- a very low level of loyalty towards the brand,

- the greatest amount of time is spent on searching information about a product and recommendations of it,

- a rather critical approach to social media,

- price, quality and guarantee have a relatively low influence.

The contemporary consumer is able to filter information efficiently and move around freely among various channels that supply it. Consumers expect high quality tailor-made products at a affordable price. The most important features that differentiate them from the earlier generation include:

- greater caution and the fact that they read information about a product or a service more carefully before it is purchased,

- the fact that they find the price to be the most important factor that influences their purchase decision, which is then followed by quality. Consumers often treat these factors on a par,

- consumer preferences evolving towards online buys. Apart from searching product and service related information the ability to make a purchase online is also starting to play a significant role (Driggs, 2012).

All Internet users are more and more willing to use newer and newer applications related to using web resources. Thanks to them users can find out about their place of rest mainly saving time. At present the comfort of acquiring information without leaving home is not the only convenience but is the one that has the greatest influence over our predispositions and preferences. Constantly increasing availability of tourist information, continued development of mobile devices and applications and recommendations from those perceived as experts in travelling are the most 
important factors that are conducive to developing new ways of travelling and spending leisure time. For this reason e-tourists have both theoretical and often practical knowledge about travelling. Those are people who value the quality of information that they have obtained and are able to use it. They have been brought up in an information society, which they are very well aware of. They often cannot afford to travel in real time and the only option they have is to travel virtually.

An e-tourist is also an e-consumer. If we were to follow a loose and very limited interpretation by MacCannell (2002), a tourist would be defined as a real human being who is flesh and blood. Yet tourists perform various functions. The word denotes real tourists - those engaged in sightseeing (usually these are members of the middle class) and scattered all over the world to search for new experiences. If we only take a broader perspective not only in the context of performing various activities that prepare us to go on a journey, it will turn out that we can consume tourist services in virtual time, which makes us e-tourists. One of the directions of consumer interests related to the development of information technologies is to take a virtual tour, which also or first of all promotes the e-tourist profile. Virtual sightseeing is a computer visualisation of real places give visitors the impression of actually being in a particular spot (based on Virtual Tours). A virtual visit cannot take place without a virtual space, which means that the former is associated with using opportunities that the Internet offers and taking up a virtual tourist space. In this case space is defined as an unreal space which theoretically can exist or exists, but not at a particular place (i.e. where an e-tourist is staying) and time (Włodarczyk, 2007, as cited in Stepaniuk). The biggest advantage of a virtual visit is that a consumer can choose all the factors related to the consumption of the positive aspects of tourism on his or her own.

Changes to the behaviours of the current consumer can be explained by an increase in his or her self-organisation which has taken place over a dozen or so years. This growth is not only caused by the increased importance of new technologies, but also first of all by a rise in trust towards people. It can be defined as community consumption which entails sharing, lending, borrowing and exchange on an unprecedented scale. The initiative has become quite popular among travellers who are usually seen as a group which is more open to new experiences than others. It is called carpooling, which is a form of hitchhiking and is an inexpensive way to travel. Using a variety of applications first on Facebook and then in many other Internet services it is possible to match drivers and potential passengers even on the websites of Polish passenger carriers as another travel option for a shorter period of time for less money. Another example of consumers organising themselves is the so called couchsurfing. Earlier a similar function was performed by Hospitality Club, which is still enjoying quite a lot of popularity among Poles. The main idea behind the initiatives is to search and find online a particular inhabitant of the city that the user is planning to go to and use free accommodation with that person. This initiative makes it possible to not only travel more cheaply, but also build closer intercultural relations.

Alterations to our behaviour as we search and buy interesting tourist offers confirm that the consumer profile is undergoing changes and that employers are adapting to consumer needs. Completing an online purchase is largely dependent on the product that has been bought. The most popular items bought online are: 
- plane tickets in the form of e-tickets (77\% of plane tickets are purchased via the Internet). The vast majority of plane tickets from low-cost carriers are available only on their websites and the fact that other companies also offer discount deals means that the tool is more and more often used because it is faster,

- a room in an accommodation facility is usually bought in a traditional way, despite the fact that booking is mainly made via the Internet. However, technological limitations of most accommodation facilities often make it impossible to complete the purchase (Figure 2).

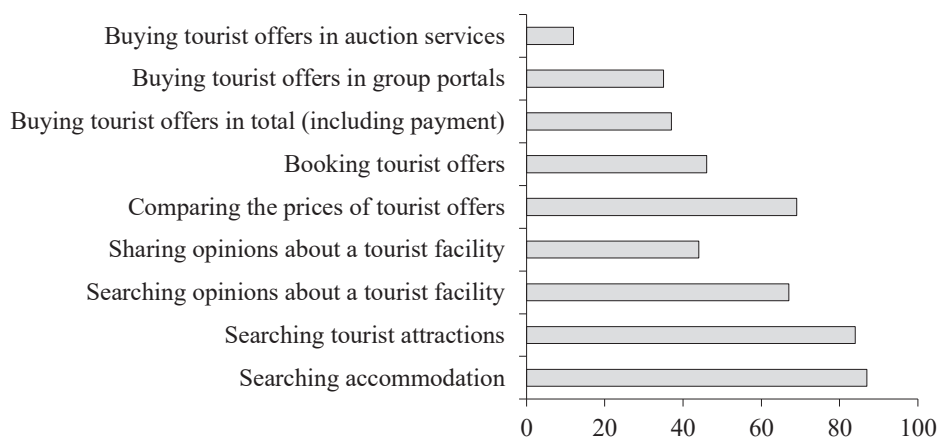

Figure 2 Possibilities of using the Internet in the decision making process and its completion as a tourist offer is bought

Source: Produkty i uslugi turystyczne w Internecie, ww.google.pl/intl/pl/adwords/resources/turystyka_2008.pdf, 2008.

Using the Internet in a variety of ways during each stage of our lives enables outlining some sort of the basis for the e-tourist profile. It can be noticed that it is a combination of two elements: saving money on purchases and devoting the least amount of time to shopping. The most important features of a e-tourist include the ability to compare the prices of goods and services, seek discounts, the reliability and reputation of sellers and active use of other people's opinions.

\section{Conclusions}

A thorough knowledge of e-consumers' behaviours is of utmost importance as seen from the perspective of corporate management. The way consumers make their decisions at the same time forces entrepreneurs to change the manner in which they promote their products and services. Consumers are more and more aware of what they want and seek indispensable information on their own. For this reason an entrepreneur should not only ensure that their website is constantly updated, but also to make sure their product is presented properly. It is also important that he or she monitors and reacts to their customers' opinions. Unfortunately recent research into companies using the Internet shows that the vast majority of entrepreneurs treat this tool in a quite conservative way and are not fully aware of the changing media space (SMG/KRC Poland Media, 2011). Therefore, as it 
has already been mentioned, companies have to continue to adapt to changes that are taking place in the consumer profile. Particularly they need to:

- constantly acquire information about various behaviours and preferences (because consumers have a wide and multidimensional perspective),

- improve numerous communication channels between a company and a consumer (even the most recent ones which are mainly used by consumers),

- undertake permanent cooperation with consumers in order to influence their buying decisions,

- make sure that constant technological development should support the relationship between the company and its customer, and not replace it.

The analysis into the consumer of tourist services in the market and the impact that the Internet has on buying decisions in that matter has enabled combining the info on the tourist himself or herself with how he or she should be approached by the entrepreneur. For this reason features such as comfort (the ability to buy round the clock), time saving, the value of a product and the ability to modify an offer are becoming quite significant benefits of an offer to be sold, including a tourist one.

\section{Referennces}

Bell D., The Coming of Post-Industrial Society: A Venture in Social Forecasting, Basic Books, New York 1973.

Castells M., The Information Age: Economy, Society and Culture. The Rise of Network Society, Vol. 1, Blackwell Publishers, Oxford 1996.

Castells M., The Information Age: Economy, Society and Culture. The Rise of Network Society, Vol. 2, Blackwell Publishers, Oxford 1997.

Castells M., The Information Age: Economy, Society and Culture. The Rise of Network Society, Vol. 3, Blackwell Publishers, Oxford 1998.

Cellary W., Wstęp, in: Polska w drodze do globalnego społeczeństwa informacyjnego. Raport o rozwoju społecznym, UNDP, Warszawa 2002.

Driggs W., Homo informaticus: Jak cyfrowi konsumenci zachowuja się w sieci, ww.ey.media.pl/file/attachment/.../4c/ ey_homo_informaticus.pdf.

Drucker P.F., The Age of Discontinuity: Guidelines to Our Changing Society, New York: Harper and Row, 1968.

Drucker P.F., Post-Capitalist Society, Harper Business, New York 1993.

Goban-Klas T., Sienkiewicz P., Społeczeństwo informacyjne: Szanse, zagrożenia, wyzwania. Wydawnictwo Fundacji Postępu Telekomunikacji, Kraków 1999.

Hatalska N., Trendbook, www.hatalska.com, Gdańsk 2011.

Jaciow M., Wolny R., Polski e-konsument. Typologia i zachowania, Gliwice 2011.

Kalecińska J., Nowe technologie w branży turystycznej, AWF, Warszawa 2013.

Karvalics L.Z., Information Society - What Is It Exactly? (The Meaning, History and Conceptual Framework of an Expression), Network for Teaching Information Society, Budapest 2007.

Kubicek H. Möglichkeiten und Gefahren der „Informationsgesellschaft“, Tübinger Studientexte Informatik und Gesellschaft, in: S. Rizvi, H. Klaeren, Universität Tübingen, Tübingen 1999.

MacCannell D., Turysta - nowa teoria klasy próżniaczej, Muza, Warszawa 2002.

Machlup F., The Production and Distribution of Knowledge in the United States. Princeton University Press, Princeton 1962. 
Porat M.U., The Information Economy, Vol. 1, Office of Telecommunications, US Department of Commerce, Washington DC 1977.

Produkty i usługi turystyczne w Internecie, www.google.pl/intl/pl/adwords/resources/turystyka_2008.pdf.

Raport Global Trust in Advertising, www.iab.org.nz/images/uploads/Nielsen_global-trust-in-advertising-2012.pdf.

SMG/KRC Poland Media, Wykorzystanie Internetu w matych i średnich firmach, 2011.

Społeczeństwo informacyjne w Polsce w 2014 roku, GUS w Szczecinie, Warszawa 2014.

Stepaniuk K., Wirtualne zwiedzanie w opinii internautów w Polsce, „Ekonomia i Zarządzanie” Vol. 3, No. 3, Oficyna Wydawnicza Politechniki Białostockiej, 2011.

Strategia Rozwoju Informatyki w Polsce. Raport I Kongresu Informatyki Polskiej, www.kongres.org.pl/on-line/1-szy_ Kongres/Raport.html .

Tarkowski A., Analiza społecznych uwarunkowań dostępu do Internetu, http://zds.kprm.gov.pl/sites/default/files/analiza_ alek_tarkowski.pdf.

Toffler A., The Third Wave, Bantam Books, New York 1980.

Virtual Tours, www.virtuar.com/virtour/virtual_tours.htm.

\section{WYKORZYSTANIE INTERNETU W PROCESIE DECYZYJNYM ZAKUPU OFERT TURYSTYCZNYCH}

SŁOWA KLUCZOWE

STRESZCZENIE społeczeństwo informacyjne, e-turysta, decyzje zakupowe

Coraz istotniejszym czynnikiem zmian staje się postępujący rozwój i upowszechnienie nowych technologii informacyjno-komunikacyjnych. Technologie informacyjnokomunikacyjne doprowadziły do znaczących przemian w komunikowaniu się, dając możliwość upowszechniania informacji bez pośrednictwa tradycyjnych mediów. Dzięki Internetowi firmy mogą tworzyć własne kanały komunikacji, skierowane bezpośrednio do obecnych i przyszłych klientów. Celem artykułu było wskazanie możliwości wykorzystania Internetu w podejmowaniu i realizacji decyzji zakupowych usług turystycznych. Artykuł został poświęcony istotnym przeobrażeniom, jakim podlega zjawisko turystyki poprzez upowszechnienie technologii informacyjnokomunikacyjnych. Internet i technologie mobilne zmieniają przestrzeń medialną, a wraz z nią także sposób komunikacji pomiędzy firmami i konsumentami. 